\title{
Implications of ethno-linguistic politics on the national integration in Pakistan
}

\author{
Muhammad Saleem*1-2 | Saiful Islam ${ }^{3}$ \\ 1. Department of Political Science, University of Peshawar, Peshawar, Pakistan. \\ 2. Department of Elementary \& Secondary Education, Khyber Pakhtunkhwa, Pakistan. \\ 3. Department of Political Science, University of Buner, Sowari, Pakistan. \\ *Corresponding Author Email: muhammadsaleem.sst1971@gmail.com
}

\begin{abstract}
The problem of national integration can be found mostly in the developing countries. The postcolonial period holds great significance in this connection. The governments of those countries did introduce different kinds of strategies to ensure national integration but failed. National integration is a big issue in Pakistan and the main reason is multi-cultural society having conflicting ethno-linguistic interests. No ruler or government seems to have honestly tried to resolve this turbulent issue. All groups living in Pakistan have many kinds of grievances. The unfair distribution of wealth is faced by all groups. The state espoused authoritarian policy to establish its position and power. Baluchistan has natural gas but is the poorest province. Similarly, Khyber Pakhtunkhwa produces electricity of Pakistan but faces more load shedding than other provinces. As for as the attainment and maintenance of national integration are concerned, provincial autonomy and strong federal institutions are the prerequisites. Only those countries have achieved national integration in the post-colonial period who have adopted pluralistic and rejected assimilationist approach. Strengthening of political institutions and federal system can redress the grievances of the oppressed groups. In this paper the researcher has tried to discuss implications of ethno-linguistic politics on national integration in Pakistan.
\end{abstract}

Keywords: authoritarianism, ethnic politics, linguistic issues, linguistic politics, federation, federal structure, pluralism, provincial autonomy, national integration.

How to Cite: Saleem, M. \& Islam, S. (2021). Implications of ethno-linguistic politics on the national integration in Pakistan. Journal of Humanities, Social and Management Sciences (JHSMS), 2(2), 119130. https://doi.org/10.47264/idea.jhsms/2.2.9

Publisher's Note: IDEA PUBLISHERS (IDEA Publications Group) stands neutral regarding jurisdictional claims in the published maps and institutional affiliations.

Copyright: ( 92021 The Author(s), published by IDEA PUBLISHERS (IDEA Publications Group).

Licensing: This is an Open Access article published under the Creative Commons AttributionNonCommercial 4.0 International License (http://creativecommons.org/licenses/by-nc/4.0/) 


\section{Introduction}

The national integration is a prerequisite for the prosperity, development and civic uplift of a country. Political, economic, educational, trade and industrial activities are dependent on national integration. The more a country is integrated, the stronger it is. Pakistan was established on the basis of two nation theory. Muslims living in different parts of the undivided India struggled tirelessly for the creation of a separate homeland for Indian Muslims. Islam and relative cultural identity played a pivotal role for the success of Pakistan movement. Pakistan faced a multitude of economic, political, military, and administrative problems since its birth. Due to weak administrative and governing setup, the governments in Pakistan failed to resolve the issues of national integration which comprised language issue, provincial autonomy and distribution of natural resources equally and justly. The negligence of these issues resurfaced the dormant sentiments of regionalism and provincialism. The post 1971 era provided an opportunity to gain experience and lessons from the irrational and undemocratic practices of the past. People wanted to see Pakistan, a strong, peaceful and developed country, but the military and political leadership failed miserably and showed apathy towards national integration and harmony.

Pakistan is a multicultural country. National integration is a big problem in those countries which have multicultural societies like Pakistan. Since her independence in 1947, Pakistan has failed to solve this problem. There are many causes of national integration issues in Pakistan. It is also a fact that Pakistan has lost one of her most important wing East Pakistan due to this problem, but no one has given importance to this problem. This problem can be solved if the rulers of Pakistan pay their attention to it. The administrative and political history of Pakistan is replete with scores of different kinds of experiments espoused by both the politicians and establishment of Pakistan for their own personal interests. Sadly, the welfare and interests of the people who were down-and-out were put aside (Zaidi, 1997). At provincial level there were fewer expectations as opposed to expectations from the central government of Pakistan. Economic interests were preferred at the expense of other equally or even more important interests. Although the newly born state was to cope with numerous challenges, history speaks volumes of its progress by leaps and bounds in terms of its attainment of harmony, stability and consistency. Therefore, it can be said that — save few incidents - the pre-1971 period was not so bad for Pakistan (Noman, 1990).

In the beginning, both the people and the leaders feasted their eyes on and were greatly passionate about the newly-born Muslim state-Pakistan; however, the demise of their charismatic leaders, Mohammad Ali Jinnah and Liaqat Ali Khan, created a huge vacuum. Evidently, there were many issues to be resolved for the sake of the survival of the country. The only hope of the people-bureaucracy along with greedy politicians-started to accumulate wealth for themselves, and, at the cost of the welfare of the nation, they tried to make policies of their personal interest. Furthermore, novel trends of corruption were invented and introduced in the politics of Pakistan. Except the sense of deprivation in the East Pakistan, there was no question of national integration except some small disputes (Fazal, 1999). The division of Pakistan in 1971 was a catastrophic loss, but the post-1971 period was not discouraging. Undoubtedly, Pakistan was up against many issues in all walks of life—of which 
some were resolved while others still exist. In a scenario like this, nations lose freedom and sovereignty. On the contrary, although East Pakistan was lost, the rulers learnt that democracy was the real solution of all kinds of disputes. Hence, elections were already held in 1970, a new parliament was called in to form the government; which passed and promulgated a new constitution - the constitution of 1973; moreover, Pakistan was declared federal state in the said constitution (Shakir, 1982).

Sindh became the hub of political activities during the reign of Gen Zia. As Sindh was the home province of Bhutto, Pakistan People Party (PPP) stated large scale activities against the regime of Gen Zia. As there was majority of Urdu speakers in Karachi, it (Karachi) became the main point of political dissidence. The influx of Punjabis and Siddhis into the city for trade escalated the grievances of the local Sindhi people (Ahmad, 2009). Urdu speakers, Punjabis and Pashtuns occupied the majority position in Karachi, rendering the Sindhi population a minority in their own province. In addition, the big industrial areas were captured by nonSindhi people. Surprisingly enough, more than $50 \%$ of the people of Karachi are Urdu speakers while the native Sindhis are only about $7 \%$. This is regarded as the real bone of contention in Sindh (Ahmad, 2002). Besides, the execution of Zulfiqar Ali Bhutto was a great setback for national integration in Pakistan in general and Sindh in particular. Unlike its position in other parts of the country, PPP is a nationalist party in Sindh. The people of Sindh regarded the execution of Bhutto as a judicial murder. The execution of ZA Bhutto had widened the gap between Islamabad and Sindh (Zulfiqar, 2011). Muttahida Qaumi Movement (MQM) is purely a Muhajir (Urdu speaking people) nationalist party and is working for the interests of Muhajirs. All the political parties of Sindh except PML (F) attract the people of Sindh on the slogan of deprivation (Shah, 2007; Gilani et al., 2017).

In Khyber Pakhtunkhwa, Awami National Party (ANP) and Pakistan Qaumi Party (PQP) derive their support from anti-Kalabagh slogans and the control of national resources of Khyber Pakhtunkhwa. In this connection, hydropower is the main issue of the people of KP. No one can deny the fact that Khyber Pakhtunkhwa is the biggest supplier of electricity to the national grid, but it is also the most affected province in terms of frequent power breakdowns (Hussain, 2009). Similarly, Baluchistan produces $45 \%$ of the fruit of Pakistan. Moreover, most of the areas of Baluchistan are rich in minerals; for instance, natural gas is supplied to the entire country from Sui plant. However, owing to the unfair distribution of coal, gas and other minerals, the national integration of Pakistan is directly challenged. Consequently, it has given birth to Pakhtunkhwa Milli Awami (PMAP) and Baluch nationalist parties (Mateen, 2003). The province of Punjab is no exception in this regard. The people of Southern Punjab always raise their voice against cruel discrimination. These and some other ethno-lingual issues engender a sense of deprivation among the masses which directly challenges the national integration. In this paper the researcher has tried to throw light upon the implications of ethnolingual politics on national integration of Pakistan.

The main research objectives of the study are: (a) to find the causes of ethnic and social unrest in the country; (b) to analyse the grievances of major ethnic groups; (c) to identify practicable and rational approaches for addressing economic and social unrest; and (d) to design a feasible framework for the solution of main problems. This paper encompasses the issues of national integration in Pakistan. Main threats to the national integration have been pinpointed. The core issues are highlighted, and the remedial solutions have been suggested. 


\section{Approaches to national integration}

\subsection{Pluralism}

In multi-ethnic states the policies of exclusion and assimilation are common however, the policy of pluralism is also in vogue in some countries. In countries where there are more than one cultures the policy of pluralism is deemed apt for the attainment of national integration. In a society where more than one cultures, religions and customs exist cheek by jowl is called a plural society. In Nigeria the society is plural (Abubakar, 1998). Similarly, in Pakistan the society is plural: except Islam, the culture, languages and customs of its people are different. However, with other feelings deprived and marginalized, one culture - that is deemed superior or mightier one way or the other-in Pakistan has taken hold of everything. Obviously, people do take a stand against the monopoly of one group and, as a result, the national integration remains a far cry (Haq, 2011). In such states the policy of pluralism is indispensable for the attainment and maintenance of national integration. In pluralism the duty of the state is to give importance to all ethnic groups whether small or big. The diverse and conflicting objectives of the groups are fulfilled (Taylor, 1992). In a multi-cultural country like Pakistan the policy of pluralism can come in handy in achieving and maintaining national integration.

\subsection{Federalism}

Federalism is also a very feasible model for national integration in multi-cultural countries. In a federation various conflicting units are yoked to make a new state. The policy of federalism is very successful in big countries like India and USA. Usually, bicameral legislature is suggested for federal state, in which one house is formed as per the population while, as for the other, all the units are granted equal representation (Portes \& Zhou, 1993). In federation units are rendered autonomous in the constitution. All the units get maximum autonomy in their areas. Except some most important subjects the remaining are given to the units. All units are given equal rights in the affairs of the state. The central government can legislate on federal list and the units legislate on provincial subjects. However, the main reason of strong federation is strong provincial autonomy. If units are happy in a federation, the centre will be powerful and vice versa (Ramakrishanan, 2012).

Pakistan is a federal state. The powers have been distributed between Islamabad and provinces in the constitution. Eighteenth amendment increased the powers of the provinces to a great extent but in reality, it is a different story, and those political parties who were involved in the amendment have been removed from the scene by a very technical method. In other words, it can be said that the policy of federalism has been deliberately failed in the country (Tonio, 2015). Actually, the federal form of government can take Pakistan to halcyon days provided that the true and honest implementation of $18^{\text {th }}$ Amendment is ensured. Hence, national integration can be achieved in Pakistan if the people of all the units are happy. More provincial autonomy will make the federation of Pakistan stronger than ever.

\subsection{Assimilation}

In assimilation different cultures are coalesced in national culture. In fact, it is a kind of social integration. Via assimilation national integration is ensured. Common culture is introduced, and people willingly give up age-old cultures and traditions. Furthermore, a new language is 
adopted by the people which is called national language. As a result of socialization process, all ethnic groups abandon their social characteristics, which brings about a colossal change in their lives (Royce, 1982). Since, intrinsically, people have strong attachment to their cultures, the process of assimilation is not as easy as it seems. The trend of cultural awareness in people has made the process of assimilation very difficult. Assimilation is a social process and is possible in those communities where people as well as leaders are social and educated. In countries like Pakistan the state is always trying to assimilate cultures in Pakistani national culture but of no avail. For this purpose, the state should formulate a policy to grant equal rights to all units. Hence, the importance of provincial autonomy and control over resources cannot be overlooked in this regard (Hayat, 2001).

\section{Research methodology}

This is a descriptive and qualitative research and the vivid picture of the political scenario of Pakistan has been analysed. The study is explored through descriptive and analytical data analysis. Data is collected from both primary and secondary sources. The sources are the official statements, books, magazines, journals, newspapers and articles from different periodicals in addition to the net and websites. In the process of data collection libraries provided handful assistance. The collected data is arranged and then analysed through descriptive and analytical data analysis

\section{Ethno-lingual issues as hurdles in national integration}

\subsection{Language issue}

The issue of language is as old as Pakistan. When Pakistan came into being, it comprised of two parts: West and East. Bengali was the language of East Pakistan and more than dozen languages were spoken in West Pakistan. To the utter surprise of the Eastern, the policy makers of newly born Pakistan proclaimed Urdu as a national language, which became the apple of discord and resulted in the separation of East Pakistan. During the first educational conference of November 1947, reforms were introduced in which Bengali language was completely removed from envelopes, order forms, post cards and stationaries. In a very short time, the freedom fighters forgot everything. As a matter of fact, $98 \%$ of East Pakistan's population had Bengali as their mother tongue, which accounted for $54 \%$ of the whole population of Pakistan. In accordance with democratic norms, the state language of Pakistan should have been Bengali. But due to elitist power politics a spoken language of only $4 \%$ of the population namely Urdu was made the only state language. The decision was strongly opposed by the Bengali population. The situation worsened to the extent that Quaid himself visited Dacca to mollify the rising anger of the marginalized (Hussain, 2016).

Soon after the demise of Quaid-e-Azam, once again the demands to declare Bengali as the national language saw surge, as students at Dacca University and leaguers pursued the cause even more vehemently. On the other hand, Syed Sulaiman Nadvi and Khwaja Nazim ud Din advocated the cause of Urdu with powerful statements, which backfired with further aggravation. The campaign soon reached a point where the constituent Assembly called on to discuss a constitutional draft whereby both Urdu and Bengali would be declared as the official languages of Pakistan. Finally, in May 1953, the bill was passed by the Assembly. Sadly, selfinterest was given preference over national interest; tolerance and patience disappeared, and 
national enthusiasm was killed. The worst followed: East Pakistan became Bangladesh, but we learnt nothing (Jahan, 1972). The example was followed suit by other ethnic groups to speak up for their own concerns, as riots in Sindh broke out. The argument back then was that since Urdu dominated the national system of governance, it should only be learnt for communicational purposes in public offices only. Though national language functions to unite a nation, in Pakistan the issue was more disputed and intertwined and fuelled further divisions (Saleem, 2008).

\subsection{The role of bureaucracy}

The relationship between bureaucracy and National integrity is very relevant in case of Pakistan, since it inherited its bureaucratic setup from the British, along with the colonial remnants. The bureaucracy managed to keep the people divide, and worked to consolidate their own power, as opposed to work for the benefits and welfare of the masses. Regardless of who ruled on the forefront-Military or civilian governments-, bureaucracy stayed as the primary instrument that formulated and implemented national policies, till Bhutto's government (Hippler, 1998). In Pakistan bureaucracy forced the various regions of the country to stay under the umbrella of one nation but failed to create a sense of nationhood in the society. No matter how much they strenuously tried to maintain the unity of the state by centralizing administration and communication, they invariably met with failure. The deprivation was felt across all the population; however, there response was different, as the nation's multi-ethnic composition would justify.

The steps from bureaucracy saw acceptance from the people of Punjab, in contrast Baluchistan and Khyber Pakhtunkhwa's people came down hard on it. The policies of bureaucracy did achieve some success in state-building but at the cost of nation-building. Bureaucracy in Pakistan is one of the most powerful institutions in the country. They have been very keenly influencing the vulnerable, politicians and the press. Even its influence over judiciary can be seen growing since Zia's regime. Democracy is pivotal to national integration; regrettably, in Pakistan democratic institutions have always resorted to bureaucracy for guidance and support. Bureaucracy thus consolidated their power through the phenomena of dependence. It's important to note that in the Ayub Khan's Government, Yahya Khan's martial law or the Bhutto's civil martial law-Policymaking was bureaucratic in nature. This followed as the politicians lacked the capability to form a policy and to implement policies. For instance, it was bureaucracy that abrogated the constitutions of 1956 and-1962; and were also involved in ending the rule of Bhutto. Among many other causes, bureaucracy's role in the East-Pakistan debacle is of utter importance. Following the 1970 elections, it interfered to postpone the date of National Assembly meeting, which proved detrimental to the cause of national integration. The bureaucracy in Pakistan is seen as supra-regional institute working towards selfsustainability rather than nation-building (Firdous, 2008).

\subsection{Ethnic issues}

Among the ethnic issues, the one regarding Pashtun ethnicity is immensely important, since it has both national and international dimensions. Former Pashtun political allies of the Congress Party launched Pakhtun national movement, demanding to rename North-West Frontier Province as Pakhtunistan in 1948. Furthermore, the external dimension of the Pakhtun ethnic issue was used by Pakistan, against the Soviets in 1980s, playing the religious card. 
Pakhtunistan issue has both an international and a regional dimension. This backfired as Pashtun identity was associated with Talibanization and militancy in the garb of Islam. Consequently, dividing Pashtuns further, which resulted in regional conflicts within the Pashtun society, as the divide between secular and religious sects was now even sharper. Unable to take sides, the state was seen as a failure by both the religious and secular among Pashtuns, the divide has propagated to other parts of the country as well (Nasir, 2004).

In 1971, the ethnic movements within Sindh were the most aware and were sound movements of the various identities inhabiting Sindh. Karachi and Hyderabad, being predominantly occupied by non-Sindhis, led to the conviction among the Sindhi Population, that they were becoming a minority in their own province. These fears had grounds, for instance postindependence settlements of Muhajirs, and the influx of Pashtuns and Punjabis owing to the large-scale industrial setup, demanding labour. In 1970s Sindhi was introduced as a compulsory subject in schools, by the PPP government, and soon riots broke out. Altaf Hussain added further complications to the already intertwined identity politics of the country, by launching his own movement for the economic and political rights of Muhajir population of the province. The movement not only aggravated the relationship between different ethnic groups, but also other aspects such as class-difference, and religious-secular aspects (Ahmer, 2019, March 23).

Baloch people constitute just 5\% of the country's population; on the other hand, they make $50 \%$ of the population of Baluchistan. Baluchistan has tremendous resources of energy, and the province is the largest in terms of area, thus attractive for the centre. On the other hand, Baloch are very vocal about their identity, owing to their population size, and being already in competition with Pakhtun ethnic group in-province, and other groups that wish to settle in Baluchistan. Owing to their population size, their stakes in devising and implementing national policies are insignificant and thus they see central government as a competitor and have vehemently responded to any measures taken by the governments to assimilate them with the mainstream, such as education, modernization, targeting tribalism, and settling people of other ethnicities. Furthermore, the state's resorted to military action, dealing with the aggrieved population, three time, 1963, 1972, and 2004. Baloch movements in response chose to deal with the centre vice versa. Thus, worsening the situation even further (Malik, 2001).

The inter-ethnic group conflict in Pakistan has been detrimental to the cause of national integration and nation-building. Mobilization of movements based on ethnic grounds has been the norm whenever and wherever economic, political or any other objectives are to be achieved. Inability to sort things out via mutual dialogue, and lack of honesty and respect of the various groups towards each other, leads to the failures of policies that would otherwise require mutual trust, and working together (Khan et al., 2020).

\subsection{The issue of provincial autonomy}

The issue of provincial autonomy was first pursued by the population of East Pakistan, and since the country unable to decide fairly and pragmatically on the issue. East Pakistan demanded for full provincial autonomy in all aspects except Défense and Foreign Affairs. The Basic Principles Committee (BPC), tasked to layout the rudimentary principles for the Constitution of Pakistan, submitted an interim report on October 7, 1950. The BPC failed to deny adequate autonomy to the provinces. Later on, Jugto Front's 21-points presented in1954, 
the demands for pure provincial autonomy found even stronger roots. Though, the proponents of provincial autonomy could be later found supporting a stronger centre in line with the 1956 constitution. The elites of East Pakistan were included in the power and decision-making structures, in order to avoid any backlash. The new constitution of 1962 with its authoritarian approach towards provinces was received negatively, and yet again the transition towards an East-West consensus, via democracy, was hindered, in Ayoub's era. This resulted in a situation of no return between the two wings, in terms of reconciliation. Initially, as a counter bargaining, they came up with the Six-Point charter of Shaikh Mujeeb ur Rahman, which led to further grievances and inability to reconcile properly and resulted in segregation. Similarly, the grievances of Baloch and Pashtun population too have been mishandled with paranoia by the state (Majeed, 2014).

A paranoid approach towards democratic process and provincial autonomy in specific has thus failed to bear any fruitful results. It has always made both economic progress and national integration a far cry. The paranoia has roots in the differential distribution of resources among the various groups, thus the groups are interdependent. Over-centralization and failure to objectively and responsibly sort out inter-provincial and centre-provincial issues can be seen as the primary issue.

\subsection{Political instability}

The political landscape of Pakistan has been elitist in nature, secondly, the more attractive government in the centre becomes, and the diverse groups compete for it even more violently. The Khans, Choudhry's and Waderas in Pakistan have used the elitist nature of politics to capture power and thus they favoured policies that benefitted them. Failure to give economic security to the masses makes it easier for political opponents to mobilize people for personal political gains, in the garb of linguistic and ethnic issues, thus adding further fuel to ethnic tensions. Thus, power politics among different contenders, including institutes such as bureaucracy and Armed forces, has been found to diminish any positive efforts towards reconciliation (Rai \& Malick, 2009).

\subsection{Regionalism issues}

Socio-economic injustice, political instability derives ethnicity-based conflicts, and in case of Pakistan the conflict derives further strength from the geographic distribution of the different ethnic populations. Thus, the ethnic conflict becomes harder to resolve owing to its regional dominance. The fragmentation has led to an ever-increasing fractions, groups, and sects, each working for group interest, thus leaving the national cause weaker. For instance, Jeay Sindh, Baloch Liberation Army, Lashker-e-Jhangui, Sepah-e-Sahaba etc, are separatist and sectarian in nature (Ahmad, 1996).

Working towards regional interests rather than the national agenda, has left the country weakened. Regional interests among the population have gained considerable attraction, this is evident from the fact, that many now love being referred to with their ethnic roots, rather than national. This divide has penetrated even further, whereby inter-ethnic conflict is also surging. This indicates that the national agenda fails to take into account the dynamics of ethno-regional groups. The conflicting goals has led to politics of self-interest, which indeed is a short-sighted approach (Kardar, 2009). 


\subsection{Economic disparity}

Being a post-colonial nation, Pakistan has suffered economically due to the distrust among the federating units and different ethnic groups, which have different economic advantages. Though the nation is united by religion, yet again, economic disparity among the federating and the use of religion for political purposes has led to its further use being redundant. Thus, leaving economic stability a powerful factor, that can decisively act to integrate the different federating units (Dawn, 2017).

The federating units enjoy different economic advantages. Baluchistan for instance is the largest province by area, and is replete with natural resources like gas, minerals and oil. But mistrust between the federal government and tribal groups have led to poor exploitation of these resources. Extractive policies of centre towards its units have miserably failed so far, though Pakistan has the capacity to become self-sufficient in energy. In addition, its harbours can be employed to give sea-routes to land-locked countries of Central Asia, but that would require political stability and regional security (Shah \& Ishaque, 2017).

It's always easier to mobilize a population by selling them an ideology, in the cloak of help to achieve better economy. Irrational Political activism, insurgency and radicalization can well be controlled if the economic policies of centre help alleviate the regional economies, and through benefit sharing with the regional stakeholders.

\section{Conclusion}

Men rarely act out of ideological reasons, instead they act pragmatically. Ethnicity and language are employed to give adhesion to otherwise political and economic goals. Pakistan since its inception failed at building a firm national identity. One of the reasons was, its diverse ethnic groups, working towards achieving absolute authority and power in the newly formed nation. The bureaucracy, primarily comprised of Urdu speaking Muhajirs, pursued the linguistic politics to such an extent that led to the segregation of East-Pakistan. On the other hand, military as an institute had Pashtuns and Punjabis as evident from its current composition. The institutional cold wars too had an ethnic factor to them, but this time ethnic groups employed national institutes to their personal or group interests. Thus, any efforts towards national integration were made redundant. True democracy on the other hand would have vested complete power to the then Bengalis, and in post 1971 era to the Punjabi population, and would be detrimental to the Baloch population. Thus, one can expect, that true federation with provincial autonomy is indispensable, if Pakistan were to achieve any success in the nation building. The state institutions need to be depoliticized and must avoid getting used for the political purposes. In addition, the different ethno-linguistic groups must refrain from politics of divide and move forward with complementing each other economically, and morally. Reconciliation must be approached with honesty and leaders must act responsibly and without paranoia to alleviate rather than add to the suffering of the poor masses. Pakistani nationalism will be firmly established, once the leaders pursuing it rise above personal and group grudges of the past, and approach towards diversity with a positive phenomenon rather than with paranoia, of it being detrimental to the country's nationalism. Supremacy of the Constitution and rule of law must be ensured breach of the Constitution must be dealt with severely. The mistrust and grievances must be resolved through CCI, and this institution must be made more powerful and autonomous. 


\subsection{Key findings of the study}

- The political institutions of Pakistan are very weak.

- In papers one can see provincial autonomy but not in practice.

- The role of media in national integration is not encouraging.

- The problems of people of units in the federation are not the priorities of the rulers.

- Social ills are present everywhere in the society.

- The dispute over NFC is a big hindrance in the national integration of Pakistan.

- International propaganda is playing an active role against the national integration.

\subsection{Suggestions for national integration}

- Strengthening of political institutions, so as to consolidate a viable political system, whereby democracy can flourish. It's important to note, that political entities must take the responsibility, and be more strategic to achieve true democratic culture. This would require abolishing personal or regional interests, and by not extending their support to anti-democratic or despotic governments.

- Federal system of government must be achieved in essence. That being said, provincial autonomy has to be delivered. Furthermore, the centre must be stripped of too much power, since the federating units in the case of Pakistan are geographically backed. As long as government at the centre is attractive, the different ethnic groups would naturally compete for it, and thus would lead to conflict and disputes. True federation and provincial autonomy are indispensable.

- Media can aggravate a situation yet to the contrary it can very well be utilized to mitigate situations. Towards national integration, media can play pivotal role, by avoiding causing frenzy among the population whenever trivial cases are involved. On the other hand, it needs to be educated on social and political correctness, and responsible media coverage, as the diverse cultural and ethnic composition of the nation would demand. Derogatory remarks against a selected group, can cause serious damage, and can have far reaching effects.

- An effort to remove social ills, and devise positive culture whereby the identities of the groups remain intact yet love for a common national identity also flourishes. These ills include corruption, illiteracy, intolerance social injustices, ethnic discrimination, poverty, frustration and tribalism etc.

- Promoting harmony among the various ethnic groups and dealing with equity. This can be achieved by promoting a culture of dialogue, and tolerance. Paranoia and mistrust among the various group needs to be avoided, with sincerity and honesty.

- Radicalization and militancy can be detrimental to the cause of national integration. This also hampers economic stability, thus paving a way for further militancy. To curb radicalization and militancy, the culture of jingoism and war heroism needs to be excluded from educational material. In coordination, sources of positive entertainment should be encouraged, though it's important to keep an eye on radical progressivism.

- Finally, we have to slowly and gradually, work towards regaining adhesion in the international arena, by channelizing our energies towards the right and humane causes. So as to strengthen our national spirit, and help to promote our national agenda, once we have achieved internal stability, and that's after we have to set out a national agenda, that isn't perceived as a threat by intra-country major stakeholders. 


\section{References}

Abubakar, D. (1998). The federal character principle, consociationalism and democratic stability in Nigeria. In K. Amuwo et al. (Eds.), Federalism and political restructuring in Nigeria (164-176). Spectrum Books.

Ahmad, F. (2002). Ethnicity, State, and National Integration. In S.M. Naseem, K. Nadvi, (Eds.), The post-colonial state and social transformation in india and Pakistan. Oxford University.

Ahmad, F. (1996). Pakistan: Ethnic fragmentation or national integration. The Pakistan Development Review, 35(4), 631-645. https://pide.org.pk/pdf/PDR/1996/Volume4/631-645.pdf

Ahmad, S. (2009). Dreams unfulfilled. Oxford University.

Dawn. (2017, September 12). National integration. Dawn. https://www.dawn.com/news/1357050

Fazal, T. (1999). Religion and Language in the Formation of Nationhood in Pakistan and Bangladesh. Sociological bulletin, 48(1-2), 175-199. https://doi.org/10.1177\%2F0038022919990110

Firdous, M. (2008). National unity. Pakistan Observer.

Gilani, S. M. S., Salim, A., Khan, N. U. (2017). The Role of Muttahida Qaumi Movement in Sindhi-Muhajir Controversy in Pakistan. Liberal Arts and Social Sciences International Journal (LASSIJ), $\quad 1(1), \quad 71-82$. https://doi.org/10.47264/idea.lassij/1.1.2

Haq, N. U. (2011). National integration and challenges to it. Journal of Social Sciences, 89-97. Hayat, K. (2001). Assimilation as tool for national integration. Social Science Journal, 156165.

Hippler, J. (1998). Problems of culture, democracy and nation-building in Pakistan. Silk Road Journal, 1(4), 6-15.

Hussain, A. (2016). Ethnic issues and national integration in Pakistan. https://www.pakistangk.com/ethnic-issues-and-national-integration-in-pakistan/

Hussain, I. (2009). The dilemma of national integration in Pakistan: Challenges and prospects. ISSRA Papers, 43-60.

Hussain, k. (2009). Main issues of Pakhtunkwah. Express Tribune.

Jahan, R. (1972). Pakistan's failure in national integration. Colombia University.

Kardar, S. (2009). Polarisation in the regions and prospects for integration.

Khan, T. A., Khan, A., \& Mehsud, M. I. (2020). Ethnic Diversity and Federation of Pakistan:

A Societal Perspective. Liberal Arts and Social Sciences International Journal (LASSIJ), 4(2), 130-144. https://doi.org/10.47264/idea.lassij/4.2.11

Majeed, G. (2014). Problems of national integration in Pakistan. Journal of Political Studies, 21(2),

67-79.

http://www.documents.pk/file/Punjab\%20University\%20(PU)\%20\%20Problems $\% 20$ of\%20National\%20Integration\%20in\%20Pakistan.pdf

Malik, M. A. (2001). Ideology and dynamics of politics in Pakistan. Emporium.

Mateen, A. (2003). Nationalist politics in Pakistan. Dawn.

Nasir, S. (2004). Rise of extremism in South Asia. Asian Printers. 
Ahmer, M. (2019, March 23). The challenge of national integration. Dawn. https://www.dawn.com/news/1471231

Noman, O. (1990). Pakistan: A political and economic history since 1947. Kegan Paul International.

Portes, A., \& Zhou, M. (1993). The New Second Generation: Segmented Assimilation and Its Variants. Annals of the American Academy of Political and Social Science, 530(1), 74-96. https://doi.org/10.1177\%2F0002716293530001006

Rai, H. A. K, \& Malick, S. O. (2009). Comparative and Development Politics. Aziz Publishers.

Ramakrishanan, S. a. (2012). The importance of the political in immigration federalism. Arizona State Law Journal Legal Studies Research Paper, 44, 1431 https://papers.ssrn.com/sol3/papers.cfm?abstract_id=2209311

Royc, A. P. (1982). Ethnic identity; strategy of diversity. Oxford University.

Saleem, M. M. (2008). National integration. Imperial Publishers.

Shah, Z. (2007). The slogan of deprivation in Sindh. Asian Journal of Political Science, 112119.

Shakir, M. (1982). On national integration. Social Scientist, 10(4), 36-44. https://doi.org/10.2307/3520327

Shah, S. J., \& Ishaque. W. (2017). Challenges of national integration in Pakistan and strategic response. ISSRA papers. https://ndu.edu.pk/issra/issra pub/articles/issrapaper/ISSRA_Papers_2nd-Half-2017/07.CHALLENGES-OF-NATIONALINTEGRATION.pdf

Tabassum, S., \& Bhatti, G. M. D. M. N. (2020). Issues of national integration in Pakistan with reference to Balochistan. Pakistan Social Sciences Review, 4(1), 204-215.

Taylor. (1992). Multiculturalism and the politics of recognition. Princeton University.

Tonio, H. (2015). 18 $8^{\text {th }}$ Constitutional Amendment and provincial autonomy. http://www.cssforum.com.pk/general/news-articles/50945-18th-constitutionalamendment-provincial-autonomy.html

Zaidi, S. A. (1997). Pakistan society: Islam, ethnicity and leadership in South-Asia. University Press.

Zulfiqar, Q. (2011, May 3). Revisiting ZA Bhutto's murder and trial. The Express Tribune. https://tribune.com.pk/story/160805/revisiting-za-bhutto\%E2\%80\%99s-murder-trial 